\title{
O USO DA METAFORA DENTRO DA MÚSICA POPULAR BRASILEIRA COMO MEIO DE INFORMAÇÃO PARA AGIR CONTRA A DITADURA MILITAR NO BRASIL.
}

\author{
Antônio Carlos Coqueiro Pereira ${ }^{1}$
}

\section{1 - RESUMO.}

Este trabalho acadêmico em forma de Artigo tem como objetivo principal mostrar a necessidade do homem em ostentar sempre uma ideologia etnocentrista para subjugar as classes majoritárias por uma classe minoritária que sustentam o poder através de um golpe militar que promulgada nos anos de mil novecentos e sessenta e quatro, sendo uma das ditaduras mais cruéis nos países da América Latina e sendo combatidas por artista de vários segmentos culturais, através das músicas de protestos, poesias, peças teatrais escritas com cunho políticos. Enfrentando torturas, banimentos, exílios e muitos até a morte por ter seus dons artísticos usados como metáfora para informar, alertar e mostrar todas atrocidades feitas pelos agentes opressor da Ditadira Militar no Brasil. Tem como metodologia bibliográfica e com enfoque nas análises do discurso de Michael Foucault e Cleudemar Alves Fernandes. Informações pesquisadas em sites, livros com documentários apresentados com depoimentos das personagem que foram vitimas dos que diziam que faziam tudo isso pelo bem da Pátria. O público alvo será aqueles estudiosos de histórias, Geografia, Sociologia e Filosofia que tem como curiosidade a história brasileira

Palavras-Chaves: A ditadura Militar; A Música Brasileira; Análise do Discurso.

\section{2 - ABSTRACT.}

This academic work in the form of an article has as main objective to show the necessity of the man to always bear an ethnocentric ideology to be able to subdue the majority classes by a minority class of the power through a military coup that promulgated in the years of nineteen hundred and sixty four, being one of the most cruel dictatorships in the countries of Latin America and being fought by artist of several cultural segments, through the songs of protests, poetry, political plays written with political stamp. Facing tortures, banishment, exiles and many to death for having their artistic gifts used as a metaphor to inform, alert and show all atrocities made by the oppressor agents of the Military Dictator in Brazil. It has as a bibliographical methodology and focuses on the discourse analysis of Michael Foucault and Cleudemar Alves Fernandes. Information researched on sites, books with documentaries presented with testimonials of the characters who were victims of those who said they did all this for the good of the Motherland. The target audience will be those scholars of history, geography, sociology and philosophy who have as curiosity the Brazilian history

Graduado em Letras - Português/Inglês; Pedagogia; Pós-Graduado em Psicopedagogia Institucional e Clínico e em Gestão Escolar; Mestrando em Gerência e Administração de Políticas Culturais e Educacionais. 
Keywords: The military dictatorship; The Brazilian Music; Speech analysis.

\section{3 - INTRODUÇÃO}

Com o presente Artigo Acadêmico, pretende analisar a importância da música popular brasileira na época mais sombria da história social e politica do Brasil, onde tudo era censurados pelos órgãos opressores e julgadores do "bem social para a pátria", mas o que escondiam eram os interesses das classes minoritárias (elite) em relação ao desenvolvimento da maioria que faziam parte da massa trabalhadora, pobre e que galgavam mais respeito e direito de ser valorizado de acordo com $A$ Constituição Brasileira. Foi cortando o direito politico, o direito a ter direito, ao senso crítico e por fim, toda forma de liberdade de expressão e de pensamento libertário.

Como seria a melhor forma de expor tudo o que passava dentro da vida social no Brasil, sem ser preso, sem ser torturado, assassinado ou desaparecido? Aí os artistas de vários seguimentos começaram a desafiar os opressores e os que estavam no poder ilegítimo com suas artes através das formas mais indiretas que foram o uso das metáforas dentro das letras de músicas, de textos teatrais para serem dramatizados, de poemas e poesias e tudo que pudessem levar para aqueles que não tinham acesso às informações dos cenários politico nacional. Muitos dos artistas ainda com todo cuidado, foram presos, muitos torturados, exilados, expostos ao ridículo e etc.

Um dos objetivos desse Artigo é para que muitos dos que não conhecem a história da música popular brasileira possam compreender que umas das armas mais eficazes contra toda opressão da época dourado do chumbo, na concepção cultural foi mostrar como o poder da palavra poderia fazer uma grande diferença na concepção intelectual da pessoa, mesmo que na parte do interior, onde o índice de analfabetismo era enorme.

Os festivais, os centros da dramaturgia, a mídia televisiva e os programas radiofônicos, de forma indireta eram mensageiros de informações para aqueles que necessitavam serem comunicados ou avisados de algo que poderiam acontecer ou que aconteceu. Alguns Artistas como Chico Buarque de Holanda, Caetano Veloso, Gilberto Gil, que recebeu o apelido pelos dirigentes opressores de "negrinho baiano", Raul Seixas, Zé Keti, Geraldo Vandré e muitos outros artistas tiveram alguma 
repressão pelos agentes da opressão. Muitos das músicas, que foram feitas da época para serem mostradas ao povo o que aconteciam na época de dourado do chumbo no Brasil, até hoje são cantadas e lembradas em grandes eventos nacionais como símbolo de liberdade contra a opressão.

\section{4 - DESENVOLVIMENTO}

\section{1 - Teor Histórico Da Ditadura No Brasil}

Para falar dos momentos mais cruciais que o Brasil já passou, venho começar com a história do homem e a necessidade de ter supremacia ideológica, de ter uma necessidade por status, poder e para com a necessidade de proteger os seus interesses, independente de como conseguir tal proeza necessária para a sustentação do que pode ser bom para ele e de quem o rodeia.

O homem sempre foi um ser cultural e social por natureza instintiva e depois por questões racionais. Mesmo que algumas vezes essas formas racionais sejam intituladas de irracionais ao longo do tempo. Vejam como podemos considerar esses fatos irracionais do passado e que trouxeram fatos racionais para o presente. No Século vigente, não pode, de forma nenhuma, desconsiderar o papel da antropologia mundial no entendimento das consequências do que foi realizado pelo homem em relação a sua formação cultural para ter uma compreensão do bem comum entre as culturas. (TOLEDO, 2004).

Se formos analisar os fatos inerentes que aconteceram época antes de Cristo, dos acontecimentos pós Cristo, na idade média e adentrar entre os séculos recentes, veremos que o homem sempre buscou uma cultura correta, a mais perfeita e a mais que chega a perfeição.

$E$ até hoje não foi encontrada essa cultura perfeita. Pode observar os impérios antes de Cristo, conquistados com guerras selvagens e com aniquilação dos mais fracos e tornando os vencidos em escravos, pode também ir à questão pós Cristo, quando o Império Romano, com o seus generais e soldados bem treinados conquistaram a Europa e uma boa parte do oriente e cada vez mais mostrando pela força a desigualdade entre os povos daquele período. Após as derrotas do Império Romano e do Império Bizantino, as evidencias sociais e formação de castas foi definindo 
quem tinha poder, quem tinha status e formação de nobres por toda Europa e demais continentes do mundo. (SERRAZES, 2013).

Império Mongol com a bravura de Genghis Khan e dos seus herdeiros, o poder dos Czares do Império Russo, o poder da dinastia hereditárias do povo chinês, as monarquias inglesas, francesas, prussianas (Alemanha), dos Clãs na Escócia, Pais de Gales, Os Maias no México, os Incas nos países Andinos, assim foi por longo da história.

As questões religiosas dentro da antropologia também fizeram as suas artes selvagens de punir o povo contra o preceito católico, patrocinada pela santa Madre Igreja que foram os anos de perseguições pela Santa Inquisição, onde usaram técnicas selvagens de torturas e de assassinatos, a enganação pela Santa Madre Igreja, quando o Papa Leão X, com sua abnegação de construir o Vaticano, enganou a fé do povo, vendendo uma coisa que não tinha valor que foi a indulgência. Pode também mencionar as perseguições aos que desenvolviam inteligência, povos de outras crenças, as tão injustas Guerras que denominaram de Santa para obrigar os povos a adotar a religião católica. (SERRAZES, 2013).

O interesse de separação religioso da Igreja católica com a formação de uma nova igreja na Inglaterra, para satisfazer o interesse do rei e percebe que na historia do mundo o etnocentrismo falou mais alto do que a busca do nós, de todos e do social libertário. Na era moderna o etnocentrismo cultural e de poder no foi diferente das demais épocas passadas.

A Guerra dos Cem Anos, as rebeliões dentro da França e da Inglaterra e as lutas separatistas dos países que fizeram parte da Grã-Bretanha e do Reino Unido, As retaliações politicas e militares entre França, Inglaterra e Espanha, os Conflitos étnicos nos Balcãs e até mesmo dentro da Irlanda por questões religiosas e politicas e dentro da Espanha que grupos separatista ETA, fizeram anos de terror nas terras Catalãs.

E para fechar a historia etnocentrista da idade moderna, vamos conhecer e lembrar a ganancia do Reino Prussiano para conquistar terras aos seus arredores por economia e por valor político.

$\mathrm{Na}$ idade contemporânea, percebe a inveja de ascensão de países europeus com poder de economia social, bélica e de desenvolvimento intelectual em frente de países que, por questões geográficas, por questões de está mais tempo na vanguarda do desenvolvimento tanto cultural, econômico industrial e comercial, 
possibilitou ser potencias na Europa e enquanto outros países não tiveram o mesmo desenvolvimento e para sobrepor aos países desenvolvidos, passaram a ter politicas de expansão por meios violentos, agressivos e cruéis.

Pode citar a guerra franco-prussiana, onde envolveram muitos países, tornando uma Europa enfraquecida e sem nenhuma perspectiva de evolução. Essas desavenças que eram por ganância territorial e econômica, passaram a ser, além disso, agora com o cunho religioso e étnico. Esses fatos possibilitaram a surgirem os conflitos internos, denominada de guerras civis por busca de quebra de monarquias, de impérios impiedosos com o povo e com a injusta distribuição de renda, poder e de direitos.

As questões da supremacia sobre o dinheiro e o do homem perpassou a idade moderna e veio à tona na Idade Contemporânea, um dos marcos mais importante e cruel e que trouxe de forma irônica o desenvolvimento tecnológico para a destruição em massa e de contrapartida a o desenvolvimento humano que até hoje está refletindo no nosso dia a dia que foram as duas guerras mundiais.

A primeira por questões econômicas e ambição de países que não chegava a caminhar para o desenvolvimento frente aos países da Europa, pretextos vis que chegaram a ter um assassinato como justificativa para ter a primeira Grande Guerra Mundial e a Segunda foi marcada com o evento da congregação racial feita por um líder fracassado da primeira guerra mundial, onde apoiou suas ideias racistas ideológicas e com a vergonha do pagamento do espólio de guerra sancionada pelos países vencedores da primeira guerra mundial e se viu um fuhrer salvador do império alemão.

Mas todos esses eventos citados acima, também propôs um desenvolvimento refletido nos dias atuais. Vemos um avanço na medicina, com o surgimento da surfa para evitar infecção em pacientes com ferimentos de toda espécies, vimos à descoberta da penicilina e da morfina, avanços nas técnicas de cirurgias, onde esse fato pode salvar milhões de vidas ao longo de suas descobertas, também pode ter um avanço na tecnologia da comunicação e da informação que prepuseram ao advento dos surgimentos de radares, rádios de comunicação sem fio por longa distancia, código indecifráveis que fez ter sucesso no campo de batalha e a busca de descobrir meios e métodos para decifrar esses códigos com a criação de computadores de grande teor de comunicação e de informações guardas em seus arquivos e que hoje usamos com facilidade por todo o tempo e momento que são os 
computadores que recebeu o nome de "Projeto Enigma" e também pode despontar os meios de transportes evolucionários que são os submarinos, os aviões a jato, os transportes anfíbios e a energia nuclear.

Pode observar nos escritos acima, que a ideologia do que pode ser um único fator verdadeiro para a minoria que deseja um bem comum separado da maioria que não consegue ter um direito conquistado para servir a todos e que não atendem esses propósitos, com truculência, arrogância, uso da maquina militar para sobressair sob aqueles que são maioria e ver amordaçados, reprimidos, foiçados com tendência a serem excluído do mundo da liberdade e isso são caracterizados por ditadura! $\mathrm{Ai}$, vamos retratar como foi à importância da música popular brasileira para enfrentar essas barbaridades opressoras ao povo brasileiro.

\section{5 - A MÚSICA NOS “TEMPOS DOURADOS DO CHUMBO” NO BRASIL}

A temática da Ditadura Militar promulgada por força opressora militar brasileira, período denominado de "Época de Chumbo", não foi só de chumbo que vivíamos, eram tempos de que o pensar era proibido, o falar envolvia castigos, o criar pedia exilio, o fazer sentia o calafrio das masmorras dos órgãos de repressão da ditadura em São Paulo e Rio de Janeiro, tinha o Fleury, Tinha o Ustra e muitos que adoravam encontrar um subversivo para que pudesse mostrar a sua raiva, a sua lealdade e porque não dizer a ganancia de atender aos pedidos dos militares, tirando a pele de quem queria liberdade, de quem queria o progresso, de quem queria ter e ver um país mais justo. (VILARINO, 2002)

"Os anos dourados do chumbo" fez com que esses anos fossem de brasas, de choques, de pancadas, de tiros, de humilhações e de uma concepção em que faziam tudo isso por bem de um país. Por trás dos militares tinham religiosos, empresários, tinham estudantes disfarçados de comunas, tinham políticos, tinham donos de emissoras de televisão e rádios, pessoas comuns que eram convocados, requisitados por empresa estatal ligada aos opressores para ganhar promoção e etc. Tinham aqueles que se fosse convocado iam por sofrer represália pelos opressores chefes da ditadura em não aceitar as proposta seriam, ele e os familiares todos declarados subversivo e por serem acusados de muitas coisas que poderiam ser mortos. Esses anos negros da sociedade, economia e politica brasileira foram de 
extremo período do medo, da desconfiança, da subjugação dos pensantes contra aqueles que queriam fazer do Brasil colônia americana. (NAPOLITANO, 1999).

O comunismo foi tratado como uma praga nacional, o socialismo em que prega a igualdade entre os componentes da sociedade era visto como uma disseminação do mal contra o bem opressor. Escolas eram invadidas, faculdades e universidades vigiadas e com telefonias grampeadas, jornais eram fechados ou muitas vezes requisitados para atender os interesses dos opressores, o país virou um barril de pólvora em que muitos desses casos, eram motivos de tortura e morte.

O direito de ir e vir eram controlado pelas forças opressoras da ditadura militar. Não escapava pessoas idosas, homens e mulheres, adolescentes e crianças e por mais absurdo, o prazer que tinham eram encontrar "uma subversiva grávida" para aumentar o nível de tortura como aconteciam nos "Anos Dourado do Chumbo". Vejam alguns acontecimento sobre a tortura de mulheres gravidas ou de pós parto:

Nem todas passaram pela mesma tortura específica que foi reservada a
Criméia. Rosa Maria Barros dos Santos, presa no DOPS de Recife no início
de 1971 , estava no início da gestação. Após as torturas, relatou à Comissão
da Verdade, "começou um sangramento cheio de pedaços de coisas".
Passou a entender o que estava acontecendo quando trouxeram
comprimidos de ácido acetilsalisílico (AAS), que sem orientação médica
pode facilitar abortos. Rosa abortou completamente, e ainda precisou
considerar isso uma sorte: "depois, conversando com a minha ginecologista,
ela falou: 'Foi uma sorte, Rosa. Você fez um aborto completo, porque se
você tivesse feito um aborto incompleto, provavelmente, você
morreria"'. (GAZETA DO POVO, 2017). A vida do cidadão brasileiro era de incertezas, de medo, de dormir a noite e não saber se no outro dia estava vivo ou morto. Muitos dessas personagens guerreira histórica do Brasil estão desaparecidos no Araguaia, nas valas de cemitérios clandestinos em algumas capitais desse país, outros têm sequelas das torturas que foram sofridas físicas e mentais, outros foram exilados e por consequência dos maus tratos tem medo do Brasil e não conseguiram voltar. (ALMEIDA, 2009).

São marcas de um Brasil sujo, vergonhoso, de um Brasil hipócrita e benevolente com as elites e por capital estrangeiro, um Brasil injusto, um Brasil de ódio e crueldade, um Brasil de extrema condição para o mau que sobressaiu ao bem, um Brasil que tem a mais imunda época em que tudo acontecia aos olhos dos que achavam as torturas uma mentira no subconsciente e que aceitava por medo e privilégios. Muitos desses guerreiros são visto hoje como vagabundos, desordeiro da ordem pública, viciados e enloucados e sem ter uma consciência do passado que 
hoje reflete em um presente que está as portas da volta dos anos dourados do chumbo.

A frente contra todas essas atrocidades vieram dos estudantes secundaristas, dos universitários, dos professores libertos e de consciência que queriam um Brasil social e democrático de verdade, onde todos tivessem o mesmo direito perante a Lei, a Justiça, a comida, a moradia e ou trabalho. Tinham alguns militares que foram de encontro a toda essa atrocidade, uns dos mais importantes foi Carlos Lamarca, professores que lutavam contra atos que não eram democráticos, que não eram para o social e para a igualdade, eu mencionam esses professores na figura de Carlos Marighella, Muitos artistas que fizeram da sua arte um instrumento feroz contra a ditadura militar e os anos "Dourados do Chumbo" que são comediantes, poetas marginalizados pela lei do chumbo, instrumentistas, cordelistas, compositores, cantores, etc. (GASPARI, 2002).

Existia a ideia na época da ditadura fazer com que a ferramenta mais importante ao combate a essas atrocidades, depois dos sequestros dos desembarcadores, cônsules, e diplomatas estrangeiros para trocar por presos políticos, veio a caça aos poetas e compositores musicais. Foi uma grande caçada para obterem informações dos cabeças que chefiavam os que lutavam contra os militares, muitos desses artistas, foram presos e torturados, levados para o exilio, alguns banidos.

A época Dourado do Chumbo contribuiu para um retrocesso artístico, mas aqueles que resistiram, fizeram com qualidade. A espada eram os poemas e a lança eram as melodias e campos de batalha eram os festivais e os shows. (FOUCAULT, 2000).

\section{6 - A ARTE E A DITADURA MILITAR.}

Ao começar esse capitulo que retrata a injusta perseguição pelos opressores da ditadura militar aos artistas da época "Dourada do Chumbo", venho mostrar uma das demonstrações mais cruel no cenário Artístico que foi a invasão do teatro Galpão pelos dirigentes opressores da ditadura. Vejam os fatos:

Durante uma apresentação da peça "Roda Viva" de Chico Buarque de Holanda, no dia 19 de julho de 1968, um grupo de cerca de vinte homens invadiu o teatro Galpão, na Rua dos Ingleses, em São Paulo e agrediram todo o elenco, incluindo a protagonista Marília Pêra.

Segundo a Folha de São Paulo o agressores "subiram aos camarins onde as atrizes estavam mudando de roupa. Espancaram-nas, tirando-Ihes a 
roupa, e praticaram atos brutais de sevicia, conforme afirmavam atores, testemunhas oculares da violência."

O grupo era do Comando de Caça aos Comunistas (CCC). Tanto na matéria da Folha de São Paulo quanto no site de Chico Buarque relatos apontam que a dona do teatro, a atriz Ruth Escobar tentou prestar queixas sem sucesso, e que policiais viram o ataque e nada fizeram. (GAZETA DO POVO, 2017).

Como pode ter percebido os repressores da ditadura não tinham barreiras que pudessem parar as suas arbitrariedades dentro do que estavam fazendo e propondo para aqueles que defendiam a liberdade. São truculentos, são raivosos, são despreparados emocionalmente e que faziam o que queriam dentro da sua "legalidade de autoridade repressora" Um ato que estão nos anais da repressão aos artistas.

Pode ter a certeza, a ditadura defendida por aqueles que não sabiam o que passavam nos bastidores da dor, da injustiça, da crueldade, da desumanidade, da agressividade com tudo e com todos é arrepiante. E quais foram os papeis dos cantores e compositores para defender e mostrar essas barbaridades no regime opressor de 1964? Foram umas das mais importantes lutas de enfrentamento frente a ditadura militar. Temos como exemplo Geraldo Vandré, Chico Buarque, que teve até a necessidade de trocar de nome para que as suas músicas fossem liberadas pela censura ditatorial da época. (HOMEM, 2009)

\begin{abstract}
Quando Chico Buarque tapeou a censura com "Apesar de você", ele despertou a ira dos censores, que passaram a vetar, sem mais nem menos, toda e qualquer canção cuja autoria era de Chico. Mas se eles achavam que dessa forma iriam barrar o cantor, estavam muito enganados. Em uma jogada pra lá de esperta, Chico usou um pseudônimo para driblar a implacável censura: Julinho da Adelaide. Foi assim que ele lançou o LP "Sinal Fechado" em 1974 e várias canções que se valiam de metáforas e dos artifícios já mencionados para se referir ao regime e lançar provocações. Uma delas foi "Jorge Maravilha", cujo verso "Você não gosta de mim mas sua filha gosta" chegou a ser interpretado como pirraça ao então presidente Geisel, já que sua filha teria admitido gostar das músicas de Chico. Julinho chamou tanta atenção que Chico chegou a dar entrevista para o jornal Última Hora incorporando o personagem - vale a pena ler aqui o depoimento do jornalista e escritor Mário Prata sobre o episódio. (GAZETA DO POVO, 2017).
\end{abstract}

Caetano Veloso, que foi um dos primeiros artistas a serem presos juntamente com Gilberto Gil, que ficaram tempos depois, libertos com liberdade vigiada e depois foram exilados para outro país. Também o caso de Tom Zé, baiano de Ipirá, que com sua irreverencia machucava o regime ditatorial com suas musicas e propagandas vinculadas a mostrar o que estava acontecendo no país. Assim, vamos 
adentrar para outros artistas compositores e cantores que defendia o povo contra o que mais assolava na época "Dourada do Chumbo" a liberdade de expressão, a livre pratica artística e a forma de ser e querer viver. Também podemos falar de Théo de Barros que com suas ideias e a sua capacidade de criar músicas que batiam fielmente na ideologia opressora dos anos "Dourados de Chumbo" do Brasil.

Houve interesse das forças opressoras em infiltrar e desestabilizar a música brasileira com o intuito de enfraquecer a qualidade da música brasileira, colocando grupos, apresentadores de programas de auditórios, grupos de adolescentes, jogadores de futebol com péssima qualidade de cantoria e de letras para os ouvintes brasileiros.

Outra personagem que incomodou a ditadura com os seus versos, suas letras de músicas foi João do Vale com o seu programa Opinião, onde faziam de forma indireta uma batida nos opressores dos "Anos Dourados de Chumbo". Zé Ketty, outro importante compositor e cantos que revolucionar as mensagens para o povo no seu teatro de Opinião que balançava o povo, umas das músicas mais ouvida na voz de Maria Bethania foi "Carcara" que era um lamento do homem do campo pobre que eram castigados pelos homens que oprimiam nos Anos "Dourados De Chumbo". João das Neves que teve a capacidade de organizar todas as peças e a cantoria da Peça Opinião que bagunçou a paciência dos opressores dos Anos "Dourados de Chumbo".

O nosso baiano que foi preso, quando, nas suas ideologias que incrementava uma nova fórmula de sociedade para o povo brasileiro que intitulava de Uma nova "Sociedade Alternativa" os homens da repressão o prendeu e depois, antes mesmo de ver seu disco recém-gravado sair no lançamento nacional que foi o disco GITA, exilado para Nova York. Portanto, o que veremos a seguir, são trechos de forma muito clara a importância do nosso artista, principalmente os compositores e cantores flechar os seios da ditadura com mensagens, muitas vezes diretas e indiretas para o povo brasileiro contra os opressores dos "Anos Dourados de Chumbo" do Brasil. (FOUCAULT, 1996).

Muitas metáforas foram usadas em letras de músicas, tendo dois sentidos no que o autor estava querendo dizer sobre a situação politica em que estava vivendo no Brasil. Muitas composições foram vistas como um lamento do povo para o regime ditatorial que faziam com que as cabeças pensantes não tivessem a liberdade As palavras de duplo sentidos fizeram com que o povo tivesse mais conhecimento 
sobre o golpe militar de 1964 em que imperava os anos dourados de chumbo. As letras das músicas tinham vários propósitos, vamos analisar o trecho da música de Ivan Lins e Victor Martins onde tina essa mensagem "Avisa ao formigueiro, vem aí tamanduá", pois tem um tom de um aviso para que os que lutavam contra o golpe, estivessem atentos, pois a qualquer horas poderiam aparecer os milicos (os policiais de Fleury). (WORMS, 2002).

\section{7 - O CRESCIMENTO E A DIFUSÃO DA MÚSICA POPULAR BRASILEIRA PARA O MUNDO!}

$\mathrm{Na}$ década de cinquenta, teve uma grande ascensão com a descoberta pelos americanos da música brasileira no nome de Tom Jobim, João Gilberto e com a crescente desenvoltura de Carmem Miranda com a propagação do seu talento através dos filmes produzidos pelo Studio Disney que fez da sua música temas de de longas e curtas metragens. Também houve uma inveja dos grandes produtores e gravadoras americanas, devido à qualidade das produções e poesias engarjadas em nossa música.

Aí começou a querer diminuir a produção de qualidade e a expansão do que as nossas gravadoras e os crescimentos dos nossos cantores e compositores na Europa e demais países do mundo. Os americanos começaram a infiltrar pessoas da área artísticas musicais em nosso país para minar a nossa qualidade e não ter muita repercussão no exterior.

Assim, começaram enviar pessoas da área musical americana para destruir a qualidade da nossa musica como Michael Sullivan, o Porto Riquenho, Paul Massadas que recrutaram apresentadores de Talk Shows como Sergio Malandro, Jogadores de futebol como Pelé, e personagens infantis como o Balão Mágicos e outros por aí. A produção musical brasileira começou ter influencia americanizada na sua produção e gravação, mesmo os produtores e cantores brasileiros começaram a gravar nos Estados Unidos do que no Brasil.

Alguns anos depois, na década de sessenta e setenta, a nossa música sofre uma pancada dura que foram as censuras feitas por lideres do regime ditatorial em querer que as mensagens poéticas fossem ouvidas e atendidas pelo clamor de nossas letras e poesias, contando as atrocidades que estavam acontecendo no Brasil. Aí entram as metáforas, o entendimento do discurso ou a analise do discurso 
de cada poesia, poema ou mesmo contexto musical em alerta ao povo o perigo da ditadura no Brasil. Começou a mostra o poder dos Anos Dourados do Chumbo na arte e na cultura brasileira. (HOMEM, 2009)

Os festivais foram restringidos a emissora televisiva que apoiava de forma indireta a ditadura, personagens do meio musical foram sendo vigiados com intensão de exilio e de até banimento do país e por incrível que pareça, foram os tempos em que mais a musica brasileira teve grandes qualidades e que os artistas eram reconhecidos como cabeças pensantes desse país. (BOURDIEU, 1996)

A música brasileira teve muito revês na trajetória histórica desse país, pois foi uma ferramenta primordial na abordagem do sofrimento do povo, desde as sagas nordestinas com o sofrimento por não ter uma política de afirmação para o seu povo e nem pelo espaço geográfico de acordo com a sua localização no Brasil, também a música foi uma suplica para a questão social e econômico de quem procurava um lamento para esquecer as suas adversidades de vida do povo e também foi uma forma de esconder os pensamentos libertários e igualitários nas suas metáforas.

Muitas músicas, poesias, peças teatrais foram censuradas e deixadas de serem apresentadas por serem intituladas de subversiva e contra a moral e os bons costumes e o Brasil ficou sendo vivendo de uma cultura que não era verdadeira e mesmo assim rica por ter um movimento de fazer com que o brasileiro pensasse como uma afronta as metáforas e sendo cada vez mais necessário a analise de discurso das obras literárias, musicais, de encenação e de qualquer natureza no Brasil.

\section{8 - O QUE É A ANALISE DO DISCURSO?}

$\mathrm{Na}$ época dos anos dourados do chumbo, o índice de analfabetismo era muito grande, o acesso dos jovens nas universidades públicas era pequeno por não ter uma política pública de afirmação do pobre, do negro, do indígena e principalmente da questão econômica do brasileiro e o acesso a essas instituições publicas eram para minoria elitista e para os filhos da nobreza econômica do Brasil.

Aqueles poucos que conseguiram entrar nessas instituições públicas começaram a se rebelar contra as injustiças sociais dentro das universidades, faculdades, escolas secundaristas, nos centros educacionais religiosos e começaram a usar a cultura como a arma principal para mostrar e sensibilizar povo o que realmente estava 
acontecendo politicamente no Brasil. Foram armas importantes, mas nem sempre teve uma compreensão efetiva pelo povo, porque as maiorias das metáforas usadas não eram compreendidas pelo povo por ter um acesso difícil à educação, à impossibilidade de muitas vezes os ingressos nas universidades e faculdades e colégios de renome públicos. Assim podemos mencionar como foi importante a análise do discurso dentro da ditadura militar no Brasil. (FERNANDES, 2018)

Análise do Discurso não pode ter uma característica de querer impor algo, tem que ter uma característica libertaria ideológica no seu contexto interpretativo ou pode ser algo de vinculação de perpetuação ideológico para quem tem não tem a sensibilidade de ver, ler e compreender o que realmente está sendo observado, o que está sendo lido e a dupla interpretação para quem está usando as formas de análise do discurso para compreender o que está no seu campo de atuação. (FERNANDES, 2018).

\begin{abstract}
Inicialmente, podemos afirmar que discurso, tomado como objeto da Análise do Discurso, não é a língua, nem texto, nem a fala, mas necessita de elementos lingüísticos para ter uma existência material. Com isso, dizemos que discurso implica uma exterioridade à língua, encontra-se no social e envolve questões de natureza não estritamente lingüística. Referimo-nos a aspectos sociais e ideológicos impregnados nas palavras quando elas são pronunciadas. Assim, observamos, em diferentes situações de nosso cotidiano, sujeitos em debate e/ou divergência, sujeitos em oposição acerca de um mesmo tema. As posições em contraste revelam lugares socioideológicos assumidos pelos sujeitos envolvidos, e a linguagem é a forma material de expressão desses lugares. Vemos, portanto, que 0 discurso não é a língua(gem) em si, mas precisa dela para ter existência material e/ou real. (FERNANDES, 2018).
\end{abstract}

Segundo a citação acima, o autor aborda que a análise do discurso não é uma língua, nem um texto, nem uma fala, para analisar é preciso elementos linguísticos existenciais para ser compreendido e interpretado na sua essência do que está sendo anunciado. Refere a fatos sociais ou ideológicos em que está dentro do contexto em que necessita ser analisado dentro de um enunciado ou do que está sendo mostrado ou encenado.

É uma forma de demonstrar de forma consciente o que pode ser inconsciente para alguns elementos envolvidos dentro do contexto social. Assim, posso associar a Análise do Discurso às produções que faziam os compositores, os cantores com suas canções de protesto ou de informações, poetas com suas poesias, os teatrólogos com suas peças escritas, tanto cômicas ou de drama e demais seguimentos artísticos da época produzidos referindo a situação triste em que 
passava o Brasil. Em varias obras literárias em que relaciona a Analise do Discurso e até mesmo na sua Ordem do Discurso, vemos uma ferramenta importante para combater injustiça e levar ao público esses fatos que aconteciam. Infelizmente, a questão educação escolar da época não favorecia tal eficácia no propósito dos enunciados vinculados pelos artistas. Tudo isso pela ganancia do poder, do privilégio que cortavam do povo ter uma politica econômica, social, educacional e uma igualdade dos direitos judiciais para todos. A ditadura deixou bem claro que 0 seu regime principal era o capitalismo e de interesse de perpetuar a ganancia de quem estava no poder. (FERNANDES, 2018).

\begin{abstract}
Analisar o discurso implica interpretar os sujeitos falando, tendo a produção de sentidos como parte integrante de suas atividades sociais. A ideologia materializa-se no discurso que, por sua vez, é materializado pela linguagem em forma de texto; e/ou pela linguagem não-verbal, em forma de imagens. Quando nos referimos à produção de sentidos, dizemos que no discurso os sentidos das palavras não são fixos, não são imanentes, conforme, geralmente, atestam os dicionários. Os sentidos são produzidos face aos lugares ocupados pelos sujeitos em interlocução. Assim, uma mesma palavra pode ter diferentes sentidos em conformidade com o lugar socioideológico daqueles que a empregam. (FERNANDES, 2018).
\end{abstract}

A formula de enganar o povo ideologicamente através do discurso na época foi a forma como era evidenciados nas redes sociais e nas oportunidades públicas sociais que aconteciam na época. Em mil novecentos e setenta, teve a conquista da copa do mundo, usado pelos órgãos opressor como uma das maravilhas conquistadas pelos órgãos opressores que estavam no governo, à mídia tanto televisiva ou radiofônica dava como mérito o governo, outro fato importante foi à obrigatoriedade de produzir música enaltecendo a pátria naquele momento e essas músicas eram tocadas frequentemente nas mídias, outra foi à armação do atentado do Rio Centro em que os militares colocavam os que combatiam a ditadura como os culpados e mandantes do tal ato. Foi divulgado constantemente nas mídias e que levava o povo contra quem fosse contra as formas de governar dos generais. Nesse contexto, venho abordar a analise do discurso como ferramenta principal nos combates informativos dos nossos artistas da época. (HABERT, 1996).

\title{
09 - CONCLUSÃO.
}


O homem sempre buscou de forma individual ou em grupo ratificar seu poder dentro de uma conjuntural social com o uso da sapiência, do jogo da oralidade, do jogo da manipulação e por último da força opressora. Esses fatos tem inicio desde o homem primitivo e foi evoluindo durante Séculos e mais Séculos até chegar nos dias atuais. Tivemos massacre em massa de povos, tivemos destruição e desenvolvimento de armas destrutivas que não escolhiam quem matar e quem deveria morrer, tivemos avanços tecnológicos através desses atos e o que mais vem entender é que o homem sempre teve uma visão gananciosa do poder no mundo. No Brasil não foi diferente, tivemos massacres e escravidão de índios, tivemos escravidão e massacres de negros, tivemos forças opressivas politicas durante o período colonial e republicano e até chegar a um extremo humilhante que foi a ditadura militar de mil novecentos e sessenta e quatro, onde tivemos massacre no Araguaia, onde tivemos torturas de jovens, mulheres homens e idosos, onde tivemos torturas psicológicas com lavagem cerebral, onde tivemos mortes com reconhecimento e mortes que ainda hoje não são reconhecidas e por último das humilhações e selvageria é ter pessoas desaparecidas que não sabe se está vivas ou mortas. Quem combatiam essas atrocidades dentro das escolas, universidades, faculdades, nos sindicatos eram pessoas comuns que não tinha conhecimento de aparatos militares (armas) e não tinha poder econômico e nem estrutural para enfrentar de igual para igual os ditadores e aqueles que os seguiam. Umas das ferramentas utilizadas como mecanismo de informação para o povo, era as músicas produzidas sobre versos e poemas de cunho de protestos, com metáforas dirigidas exclusivamente para o povo e muitas vezes sendo censuradas e seus produtores sendo presos, torturados, desaparecidos, levados para condições sub-humanos e humilhantes, banidos, exilados e sendo constantemente vigiados pelos órgãos opressores do governo da ditadura. Neste contexto, esse trabalho acadêmico vem mostrar como as músicas produzidas na ditadura militar no Brasil tiveram cunho importante na questão da informação, de rebeldia contra quem estava impondo uma política de atraso para a maioria do povo brasileiro, contra a tortura, contra o desajuste social em que encontrava o povo brasileiro na educação, na economia financeira, na desigualdade populacional e quanto regional. A musica foi umas das armas mais eficazes dentro do regime dos "Anos Dourados do Chumbo" no Brasil. 
10 - REFERENCIAS BIBLIOGRAFICAS.

ALMEIDA, Criméia Schmidt de; et al. Dossiê Ditadura: Mortos e Desaparecidos Políticos no Brasil (1964-1985). 2.ed. revista, ampliada e atualizada. São Paulo: Imprensa Oficial do Estado de São Paulo, 2009.

BERNARDO, Cláudio José. A MPB como Recipiente de Protestos Contra a Ditadura Militar: As Metáforas, Carregadas de Vozes Conta o Regime Autoritário, UERJ. 2002.

CAROCHA, Maika Lois. Pelos Versos das Canções: Um Estudo Sobre o Funcionamento da Censura Musical Durante a Ditadura Militar Brasileira (19641985). Rio de Janeiro: UFRJ, 2007

BOURDIEU, Pierre. Razões práticas: Sobre a teoria da ação. 9. ed. São Paulo, Campinas: Papirus, 1996.

BRASIL. COMISSÃO NACIONAL DA VERDADE. Relatório / Comissão Nacional da Verdade. - Brasília: CNV, 2014. 976 p. - (Relatório da Comissão Nacional da Verdade; v. 1), 2014

DUARTE, Geni Rosa e GONZALEZ, Emílio. Pensando a América Latina: Música popular, política e ensino de história. In CERRI, Luiz Fernando (org.) Ensino de Histórias e educação: olhares em convergência. Ponta Grossa: UEPG, 2007.

FERNANDES, Cleudemar Alves. (Re) Tratos Discursivos do Sem-Terra. Uberlândia: EDUFU, 2007.

Interação Social e Formação Discursiva no Movimento de Luta pela Terra. Tese de Doutoramento. São Paulo: FFLCH/USP, 2001. (mimeo).

Os sujeitos e os discursos na História. In: FERNANDES, Cleudemar Alves et al. Sujeito, Identidade e Memória. Uberlândia: EDUFU, 2004 (Lingüística in Focus) (p. 108-119). 
. Terra: um Signo Plural. In: FREITAS, Alice Cunha; CASTRO, Maria de Fátima F. Guilherme. Língua e Literatura - ensino e pesquisa. São Paulo: Contexto, 2003. (p. 109-122).

A Constituição da Análise do Discurso na Lingüística. In: FIGUEIREDO, Célia Assunção, et al. (orgs.). Lingua(gem): Reflexões e Perspectivas. Uberlândia: EDUFU, 2003. (p. 33-46).

. História e Lingüística: formação e funcionamentos discursivos. In:

SANTOS, João Bôsco Cabral. Análise do Discurso: unidade e dispersão. Uberlândia: EntreMeios, 2004. (p. 43-70)

; FERREIRA, Luzmara Curcino. Terra no Discurso do Sem-Terra do Triângulo Mineiro: aspectos estilísticodiscursivos. In: Letras \& Letras. Uberlândia: Universidade Federal de Uberlândia, V. 15, N. 2, jul./dez. 1999. (p. 1928).

; FERREIRA, Luzmara Curcino. Discursos em Confronto Veja e Bundas, o MST em questão. In: GREGOLIN, Maria do Rosário, et al. (Orgs.). Análise do Discurso: entornos do sentido. São Paulo: Cultura Acadêmica / Araraquara: UNESPCAr - Laboratório Editorial, 2001.

; ALVES Jr., José Antônio. Mutações da NoçãoConceito de Sujeito na Análise do Discurso. In: III Seminário de Pesquisas em Análise do Discurso - ujeito e Subjetividade. Uberlândia: UFU, 2008.

FOUCAULT, Michel. A Arqueologia do Saber. Rio de Janeiro: Forense Universitária, 1995.

A Ordem do Discurso. São Paulo: Layola, 2000.

A Ética do Cuidado de Si como Prática da Liberdade. In: MOTTA, Manoel Barros da. Ditos \& Escritos V - Michel Foucault: Ética, Sexualidade, Política. 
Tradução de Elisa Monteiro e Inês Autran Dourado Barbosa. Rio de Janeiro: Forense Universitária, 2004. p. 264-287.

FOUCAULT, Michel. A Ordem do Discurso. 5ª Ed. Edições Loyola. São Paulo. 1996.

GABRIEL, Glória Cristina. A Recepção das Músicas de Chico Buarque na Ditadura Militar: O Universo Feminino não Cala, Fala! PUC/RGS: 2005.

GASPARI, Elio. A Ditadura Envergonhada. São Paulo: Companhia das Letras, 2002, p. 155. 10 Idem, p. 155-156.

HABERT, Nadine. A década de 70. 3.ed. São Paulo: Ática, 1996.

HOMEM, Wagner. Histórias de Canções: Chico Buarque. São Paulo: Leya, 2009.

MACEDO, José Rivair e OLIVEIRA, Marley W. Brasil uma História em construção. São Paulo: Editora do Brasil, 1996.

NAPOLITANO, Marcos. Seguindo a Canção: Engajamento Político e Indústria Cultural na Trajetória da Música Popular Brasileira (1959/1969). São Paulo: USP, 1999.

PALMAR, Aluizio. Canções de Chico Buarque no Contexto da Ditadura Militar. Disponível em :http://www.documentosrevelados.com.br/geral/as-cancoes-de-chicobuarque-no-contexto-da-ditadura-militar.

PINHEIRO, Manu. Cale-se: a MPB e a ditadura militar. Rio de Janeiro: Livros llimitados, 2010.

ROJO, Roxane. Letramentos Múltiplos, Escola e Inclusão Social. São Paulo: Parábola. Editorial, 2009. 
SADER, Eder. Um Rumor de Botas: A militarização do Estado na América Latina. São Paulo: Pólis, 1982.

SERRAZES, Karina Elizabeth. Fundamentos e Métodos do Ensino de História. Batatais: Ação Educacional Claretina, 2013.

TINHORÃO, J. R. (1978). Pequena História da Música Popular. Petrópolis: Vozes.

TOLEDO, Caio Navarro de. O Governo Goulart e o Golpe de 64. 4.ed. São Paulo: Brasiliense, 1984. Tradução de Elisa Monteiro e Inês Autran Dourado Barbosa. Rio de Janeiro: Forense Universitária, 2004. p. 264-287.

VILARINO, R. C. (2002). A MPB em Movimento: Música, Festivais e Censura. 4 a . edição. São Paulo: Olho D’Água.

WORMS, Luciana Salles \& COSTA, Wellington B. Brasil Século XX ao Pé da Letra da Canção Popular. Curitiba: Nova Didática, 2002.

11 - REFERÊNCIA DE DITE DA WEB.

https://outline.com/U2jfk5 